Anastasiia Kuznietsova
Doctorat en linguistique
Université Sorbonne Paris Cité
ORCID ID 0000-0002-7256-8215
anastasiia.kuznietsova@gmail.com

\title{
Online language use and identity of Ukrainian diaspora in Germany
}

\begin{abstract}
This article studies the language use and identity of Ukrainian communities in Germany on the websites and in online social media. Since 2014, the conflict in the East of Ukraine has led to a remarkably large and intense flow of Ukrainian migrants to Western Europe and Germany in particular giving rise to longstanding issues of identity formation and language use both within Ukraine and inside Ukrainian diaspora communities around the globe. This article examines Ukrainian diaspora in Germany on the subject of language ideologies, practices and identity shaping by analyzing its linguistic online activity. To do so, our analysis draws on a range of interdisciplinary methodologies, including studies of descriptive reporting of diaspora's online discussions, its language practices and attitudes, and studies of discursive constructions of nationhood, which explore language indexing in relation to national identity negotiation. It is stated that Ukrainian is used as the default language on websites and in social media communication, and is central in those interactions (German and Russian are used to considerably lesser degrees). As the analysis demonstrated, it is rather difficult to find a vast breadth of sources where speakers used language code-switching. However, there appeared to be more use of code-switching and linguistic variety on Facebook groups (mostly between Russian and Ukrainian languages) than websites, perhaps because the latter two are viewed as being slightly archaic for communication purposes of the community.
\end{abstract}

Keywords: identity; language use; primary language; social media; Ukrainian diaspora.

\section{INTRODUCTION}

Our research aim is to study the language use and identity of Ukrainian speaking communities in Germany on specific websites and in online social media. Due to the work of Matthias Lücke and David Saha (2019) we know that since 2014 due to conflict with Russia there is a growing rate of Ukrainian immigrants observed in Germany. According to the Labour Force Survey with 1.2 million regular immigrants at the end of 2017, the EU is now by far the largest region of destination for migrants from Ukraine where Germany is the most popular destination country after Italy. ${ }^{1}$

The recent growth of the Ukrainian diaspora in the EU countries makes its language use and identity a perspective topic of sociolinguistics study. According to Sonia Hirt, the main challenge of Ukrainian diaspora and other 'FSU migrant studies' in West European scholarship is the flattening of diverse histories and multiple trajectories under a common denominator ${ }^{2}$ - whether 'Russianspeakers', or 'post-Soviets' thus ascribing to these communities Russian as the primary language of their communication.

Therefore, our online language use analysis aims to identify the primary language and code switching of Ukrainian social media platforms as Androutsopoulos (2006) found that the languages that multilingual speakers choose to use online are "tailored to the requirements of different modes within a website" and also can be used in certain ways to show one's identity online.

\footnotetext{
${ }^{1}$ Lücke, M., \& Saha, D. (2019). Labour migration from Ukraine: Changing destinations, growing macroeconomic impact. German Advisory Group, Policy Studies Series, p. 9.

${ }^{2}$ Hirt, S., Ferenčuhová, S., \& Tuvikene, T. (2016). Conceptual forum: The "post-socialist” city. Eurasian Geography and Economics, 57(4-5), 497-520.
} 


\section{METHODOLOGY}

Social media data were collected from websites of Ukrainian communities and Facebook groups in Germany (the website of the Association of Ukrainian Organizations in Germany and German-Ukrainian Association Rhine-Neckar; Facebook groups of Ukrainians in Germany and Ukrainians in Berlin) basing on follower numbers, the variety of language use, frequency of posts, and the variety of their social, cultural or political focus. Facebook has been chosen as an additional source because of its very public nature apt for the highly-performative aspects of identity shaping work. ${ }^{3}$

Building on previous social media data-based research into identity, ${ }^{4}$ the studied content in this article include verbal and/or visual texts (announcements, inquiries, articles) supplemented by analysis of the accompanying "discussions", comprising comments. This data is classified by Bazeley as "descriptive reporting" of participants' language practices and attitudes. ${ }^{5}$

\subsection{Research Questions}

Our main research question is as follows:

- How do Ukrainian migrant groups residing in Germany establish and use their native language via social media platforms and how this use is related to their identity construction?

We also used the following tasks to guide us upon our research:

1. To study the Ukrainian communities in Germany.

2. To compare different types of media and see how they are used.

\section{RESULTS AND DISCUSSION}

\subsection{Ukrainian Websites in Germany}

Te first website we decided to choose for our study is the Association of Ukrainian Organizations in Germany.

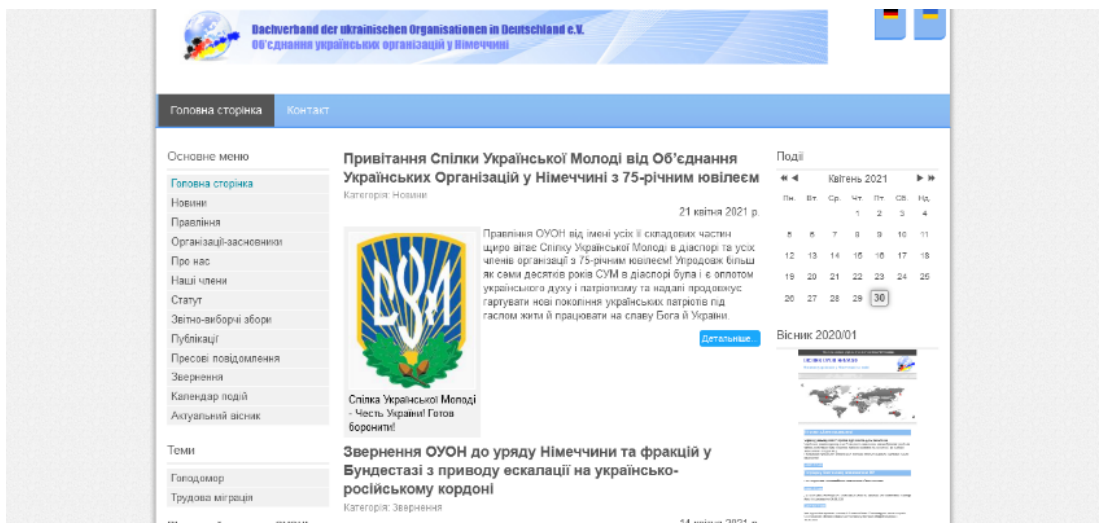

Fig. 1. Homepage of the Association of Ukrainian Organizations in Germany

By analyzing its content and structure we came to conclusion that the website appears to be extremely influential and a hub for Ukrainian communities across the country. The Association is in partnership with such organizations as Association of Ukrainian Women in Germany, Youth Union in Germany, Union of Ukrainian Students of Germany, Organization of Ukrainians in Franconia, Rhine-Neckar German-Ukrainian Society, Association of Ukrainians of Northern Germany, Ridna Shkola Society and Bereginya Society. It shows that the website is an informative

\footnotetext{
3 Dailey-O'Cain, J. (2017) Trans-National English in Social Media Communities. Palgrave Macmillan. Series on Language and Globalization, p. 55.

${ }^{4}$ Androutsopoulos, J. (2006) Multilingualism, Diaspora, and the Internet: Codes and Identities on German-Based Diaspora Websites. Journal of Sociolinguistics, 10(4), 520-547.

${ }^{5}$ Bazeley, P. (2013) Qualitative Data Analysis: Practical Strategies. SAGE Publications Ltd, p. 373.
} 
source for Ukrainian residents in Germany to maintain their cultural heritage and to lobby the interests of Ukraine abroad, which is demonstrated by a recent publication of Appeal of the Association to the German government and factions in the Bundestag regarding the escalation on the Ukrainian-Russian border (see Fig.2).

Additionally, looking onto the news section of the Ukrainian version, we may observe brief event titles and a first article part which is similar in German translations on German version of the website. However, it is clear from the screen shot below that there are no comments from users which shows there is not a great deal of communication between Ukrainian speakers on this website, which seems to be more informative than communicative platform.

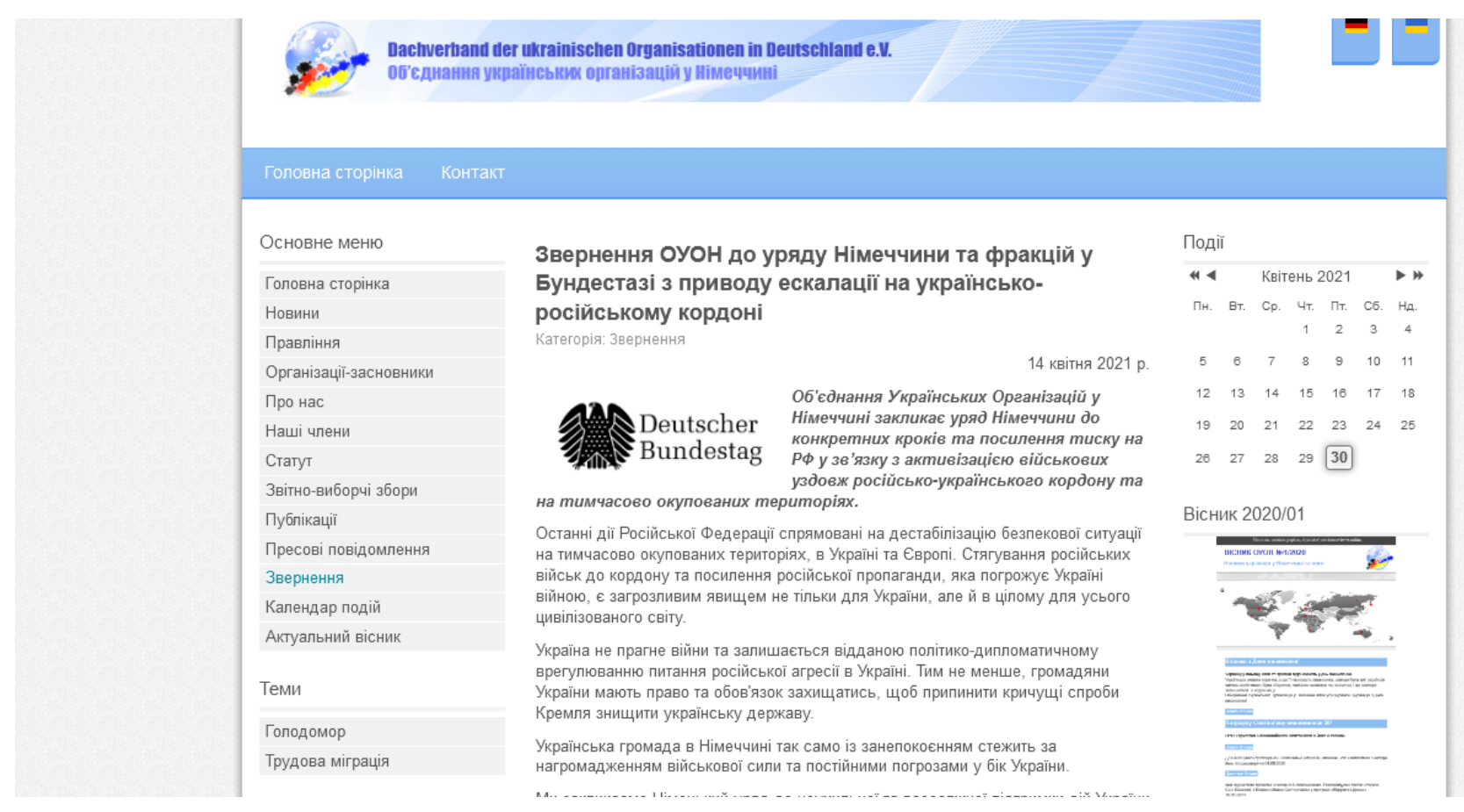

Fig. 2. Latest News section of Association of Ukrainian Organizations in Germany site

Furthermore, there is very less Ukrainian used than German (with less subpages in Ukrainian version of the website) which is probably due to the fact that the Association's webpage is not entirely exclusive to Ukrainian speakers and aims to appeal to German authorities and also people who wish to participate in fundraising as the special page for donations exists on the German version of this website but not on Ukrainian.

The second website we have chosen is German-Ukrainian Association Rhine-Neckar based in Heidelberg as the most actively updated (basing on the publication dates of the latest news) and demonstrating the most comprehensive activity among all Ukrainian organizations in Germany. The Association was founded in December 1992 by Dr. Ludeman (philologist, specialist in the history of Eastern Europe). Today it consists of Ukrainian and German members from the federal states of Baden-Württemberg, Hesse and Rhineland-Palatinate. 


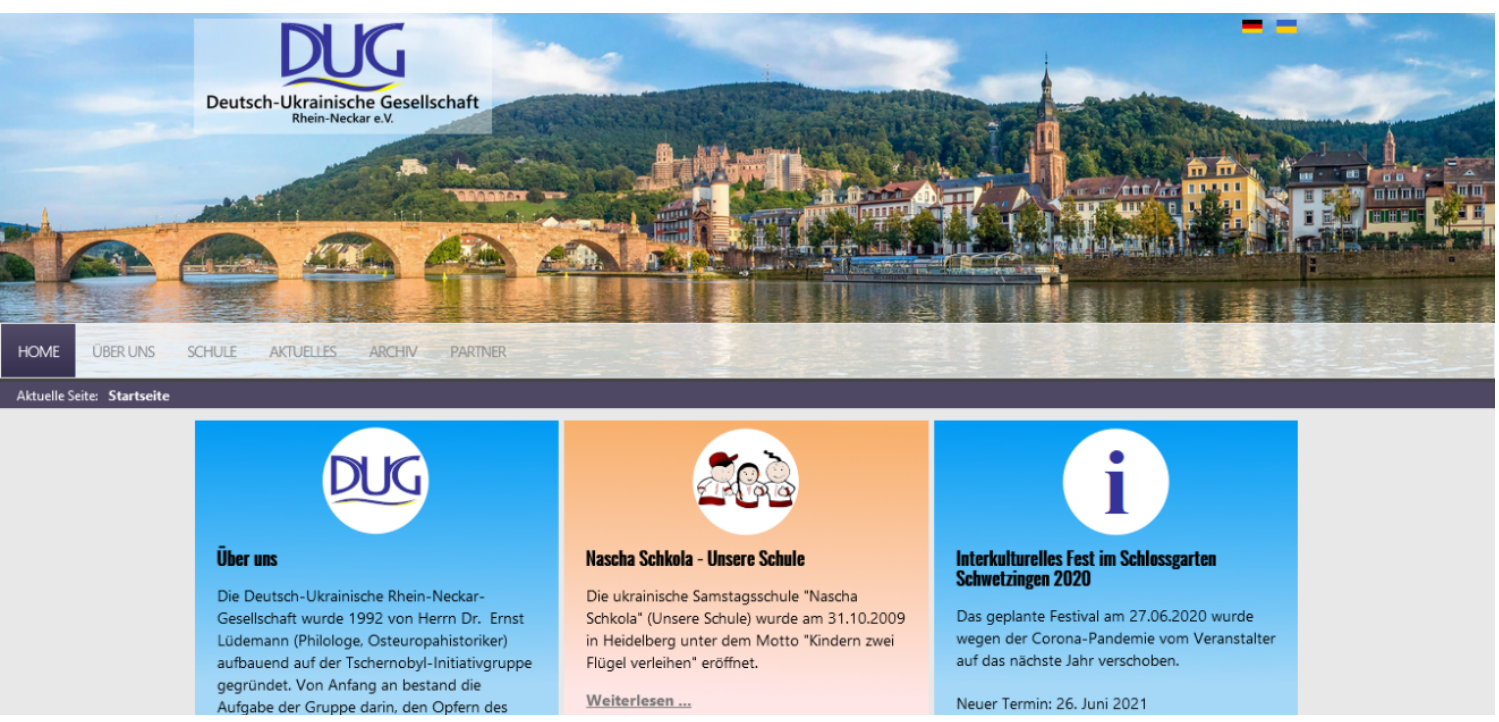

Fig.3. Screen shot of the homepage in German

The layout of the website is designed formally, like one would expect for an official community website. On one of the sections, it explains the history of the Ukrainian Community in Heidelberg and advocates the importance of the Ukrainian migrants keeping their native routes and national identity.

Linguistically, the website does have an option to translate into German, however, even on the German page, there are still Ukrainian segments written which restates that the use of this website is destined for the Ukrainian community in Heidelberg to keep it active and have the social contact. As shown below on the German translated version, the Ukrainian sentences about the Saturday school schedule and events are still used, thus encouraging newcomers of the Ukrainian diaspora to know and learn more about the community (see Fig. 4):

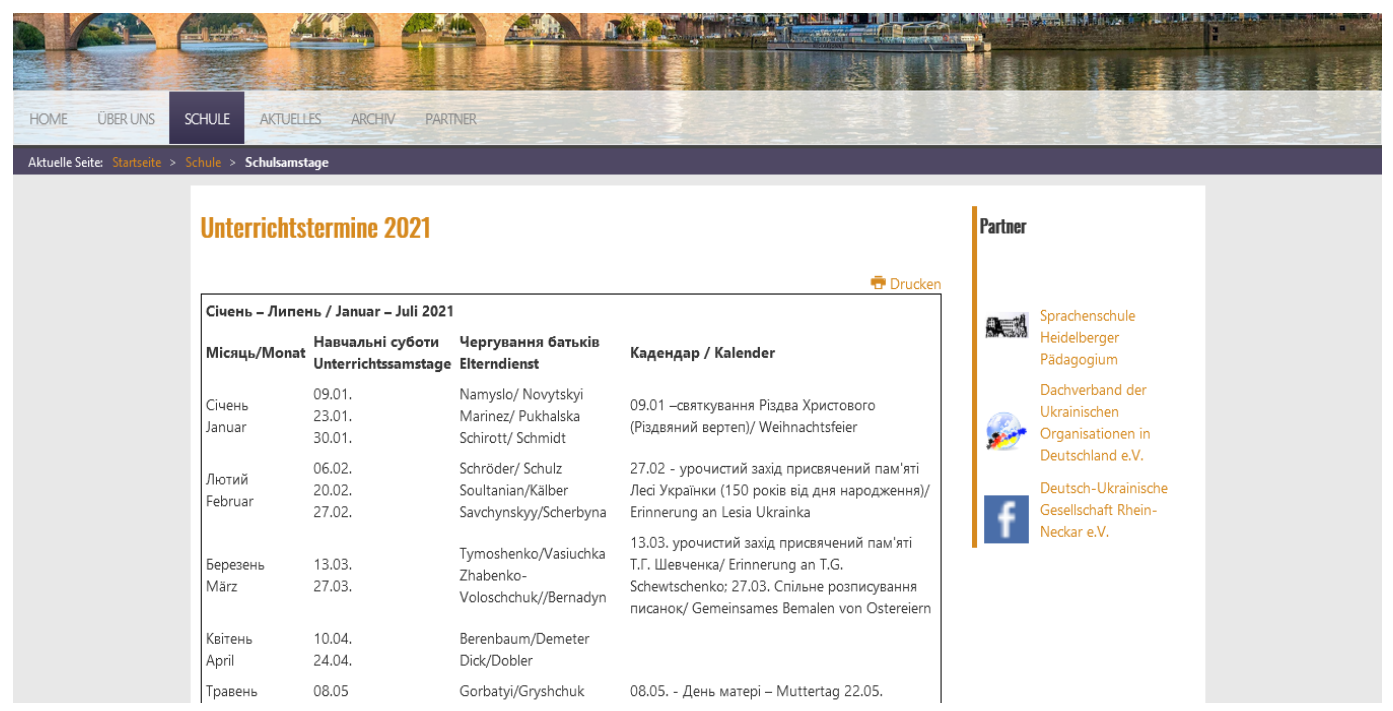

Fig.4. Screen shot of a section in the German translated format of Ukrainian being used

\subsection{Ukrainian Facebook Groups in Germany}

For our analysis we have chosen the two largest Ukrainian Facebook groups in Germany. The first is Ukrainians in Germany (Українці в Німеччині) counting 45,400 followers, which was found in 2017 and operates on controlled membership granted by administrators based on Ukrainian origin or citizenship. Whereas the group Ukrainians in Berlin ('Українці у Берліні') was found in 2018 and currently has 6700 members. 


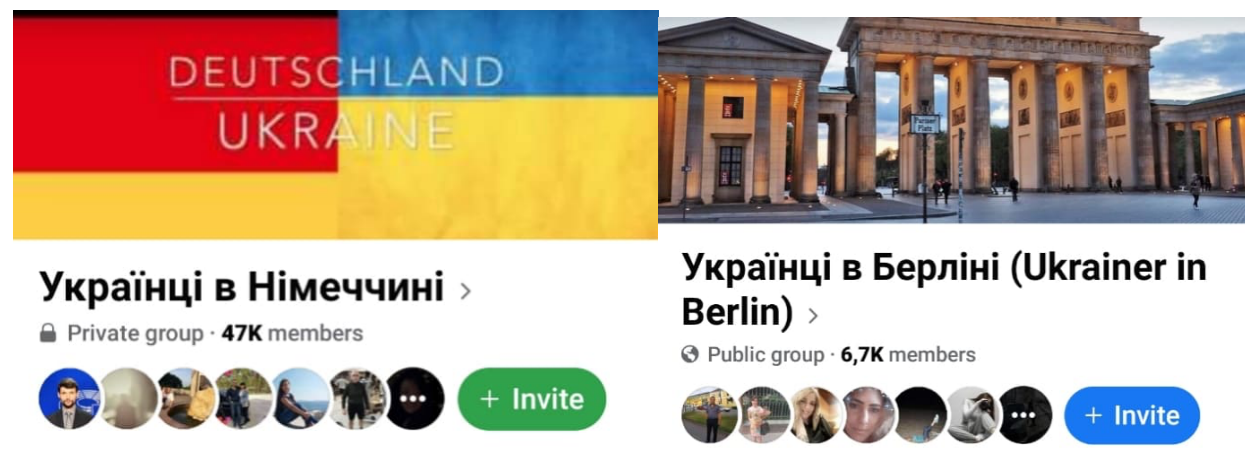

Fig. 5. Ukrainians in Germany ('Україниі в Німеччині') and Ukrainians in Berlin ('Украӥнці в Берліні') Facebook page

Both groups have been running as a platform for discussions considering work \& money, health, education, important places in Germany, communication \& travel, government \& local authority information and the news from the homeland.

Due to privacy issues, we were unable to check the identity of the participants to see whether they're native Ukrainian speakers or are just of Ukrainian heritage so therefore could only go off the names provided by the members of the group. We analyzed the first 15 most recent posts of each Facebook group within the period between $20^{\text {th }}$ to $24^{\text {th }}$ April 2021 to see which is a primary language of their communication and whether multiple languages were used.

In the majority of posts and discussions, the first language of choice is Ukrainian (10 out of the 15 posts in both groups) and show the evidence of Ukrainian-Russian code switching as the posts in Ukrainian are followed by comments in Ukrainian and Russian as shown below:

(A) ${ }^{6}[\mathbf{U}]^{7}$ Good day to all. Maybe someone knows whether its allowed to cross the border (not a visa, but under the student program ZAV) with a three-year-old child?

(B)[U] Do you have a permit to take the child?

(A)[U] We go with my husband together. What permission are you talking about?

(C)[R] The child must obtain a visa for family reunification. Find the list of documents on the website of the Embassy of Ukraine.

However, some posts are posted in Russian, as illustrated by example below with a request to find a Russian speaking doctor:

(A)[R] Please help to find a Russian-speaking gynecologist in Leipzig who knows.

(B)[U] I know there is one in Halle.

(C)[R] In the center near Höfe am Brühl there is Frau Metzler.

(D)[U] There is a group of Ukrainians in Leipzig.

(E)[U] Make the Germans learn Russian! What a disgrace!

(F)[U] You must go into the community - the Russians of Germany.

(G)[U] You need to go into the community of Russians.

From the comments of this post, we may also see that speakers E, F and G clearly display their dissatisfaction with the fact that the author is willing to have a Russian speaking doctor in nonRussian speaking country and perhaps by the fact that the request is posted in Russian. However, it is the only case of such reaction as in the other posts analyzed the comments in Russian and Ukrainian of different content coexist without any negative attitude to bi- or multilingualism as shown on a further post in the same group where an occasional Ukrainian-German code-switching is also found (user $\mathrm{C}, \mathrm{G}$ and $\mathrm{H}$ ) which is prevalent among multilingual speakers:

(A)[U] Prompt a proven company for employment on a Polish visa!

\footnotetext{
${ }^{6}$ In examples, personal names have been changed to ensure anonymity of the participants.

${ }^{7}$ All examples are presented in English, as this is the practice followed by EWJUS. The original language of interaction is indicated as follows: [U] - Ukrainian, [R] - Russian, [G] - German. All translations are mine.
} 
(B)[U] I also want to find such a company.

(C)[R] There are no such companies, you cannot work legally in Germany on a Polish visa.

You can only work in Poland. If you do not believe me, then write this question in the group.

Laws of Germany, where you will get answer from lawyers.

(E)[U] Zoll has an exact information:))) ...

(F)[G] Zoll.

(G)[G] Bundespolizei und Zollamt.

In the example above, speaker A begins his appeal in Ukrainian. Speaker C communicates in Russian, speaker E code-switch between Ukrainian and German, and finally speaker $\mathrm{F}$ and $\mathrm{G}$ responds in German.

There was not much Ukrainian-German code-switching found, however, the local germanised Ukrainian slang is attested. Thus in the discussion of Ukrainians in Germany about the transportation services in one of the comments the group member chooses instead of Ukrainian дякую (dâkuй) [thank you] to use the neologism дякуюшон (dâkuйšon) created by composition of дякую and transliterated second part of its German equivalent dankeschön [thank you] to demonstrate a multilingual skills and perhaps an established status in the local community as an "expert," by using the slang, which as this user marks, the Ukrainians of Bavaria are aware of and know:

(A)[U] Hey folks! Who can go on Saturday afternoon or Sunday morning from the Munich area to Poland, and maybe even to Ukraine?

(B)[U] We will go tomorrow.

(C)[R] Viber +38067XXXXXXX. Write to me.

(A)[U] Dâkuîšon.

(E)[U] I have not heard such word - dâkuûšon.

(A)[U] This way we say in Lower Bavaria.

Finally, the only post which entirely uses German language was found in an advertisement of online German courses in the Facebook group Ukrainians in Berlin. As we can judge from the Ukrainian surname used in the nickname of the author and his Facebook page - it was written by a German based business founded by Ukrainian native speaker which as indicated in the post resides in Germany for more than 5 years:

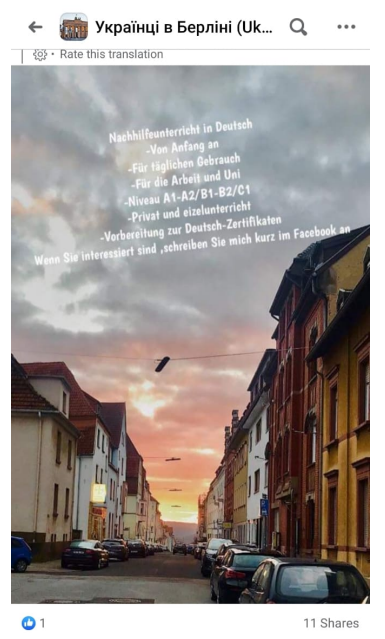

Fig. 6. Ukrainians in Berlin - post in German to advertise German online courses

In the same Facebook group, the Ukrainian-English code switch is also used in the name of the banner to advertise international transportation services from Ukraine to Germany, Belgium and Netherlands as shown in on the screenshot (probably taking into account that the author may address not only to German or Ukrainian/Russian speaking customers). 


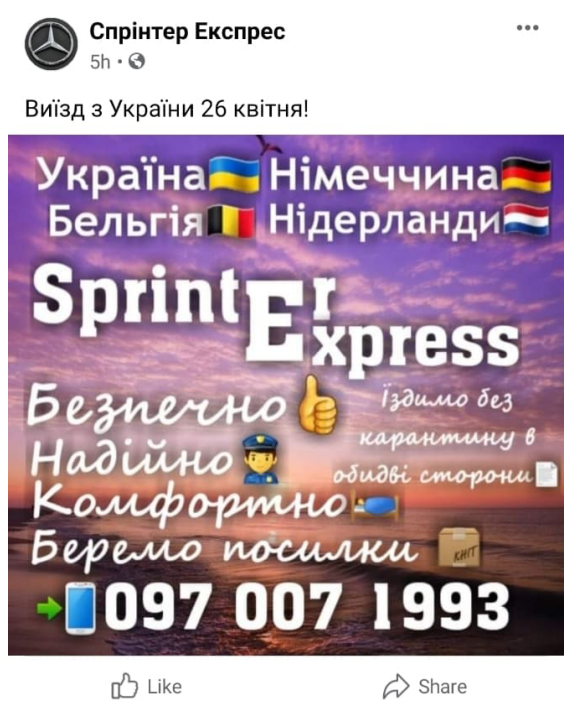

Fig. 7. Ukrainians in Berlin - Ukrainian-English code switch in the banner

Apart from these discussions, the other posts in these groups were purely written in Ukrainian followed by Ukrainian and in the lesser extent by Russian comments.

We presume that a possible reason for the high proportion of Ukrainian language choice on these Facebook pages may be because the users are actively encouraged to keep their national identity as we may conclude from the names of these groups and especially from Ukrainian in Germany groups' testament: We invite everyone who support pro-Ukrainian sentiments on this social network. /Those who are in love with Ukraine and believe in its future.

\section{CONCLUSIONS AND SCOPE FOR FURTHER RESEARCH}

Our research aimed to analyze the content for both the Ukrainian websites and Facebook groups speech on the subject of primary language use and language code-switch. Our first conclusion is that Ukrainian is used as the default language on websites and in social media communication, and is central in those interactions (German and Russian are used to considerably lesser degrees). The only one case of negative attitude towards the Russian language use on the Facebook post was also indicated. However, the low number of such criticism might also underline the acceptance of Russian-speaking Ukrainians into the community.

As the analysis demonstrated, it is rather difficult to find a vast breadth of sources where speakers used language code-switching. However, there appeared to be more use of codeswitching and linguistic variety on Facebook groups (mostly between Russian and Ukrainian languages) than websites, perhaps because the latter two are viewed as being slightly archaic for communication purposes of the community.

In fact, the positioning of Ukrainian as the central language of the studied online resources may be viewed as an assertion of a Ukrainian identity in the Ukrainian diaspora in Germany and demonstration of an ideology of state language use in the public space. This language practice may be specified as a form of "language display" or "iconization of language", signaling a process of perhaps Ukrainianization of the studied community.

Overall, by comparing and contrasting our findings from different media sources, we may conclude we were successfully able to identify our research question and focal point, how Ukrainian groups residing in Germany establish and enforce their state language via social media platforms and which influence does it have on the identity construction.

\footnotetext{
${ }^{8}$ Coupland, N. (2012). Bilingualism on Display: The Framing of Welsh and English in Welsh Public Spaces. Language in Society, 41, p. 1.

${ }^{9}$ Irvine, T., \& Gal. S. (2012). Language Ideology and Linguistic Differentiation. Regimes of Language: Ideologies, Polities and Identities, p. 37.
} 


\title{
REFERENCES
}

Androutsopoulos, J. (2006). Multilingualism, diaspora, and the Internet: Codes and identities on German-based diaspora websites. Journal of Sociolinguistics, 10(4), 520-547.

Bazeley, P. (2013). Qualitative Data Analysis: Practical Strategies. SAGE Publications Ltd.

Coupland, N. (2012). Bilingualism on Display: The Framing of Welsh and English in Welsh Public Spaces. Language in Society, 41, 1-27.

Dailey-O'Cain, J. (2017) Trans-National English in Social Media Communities. Palgrave Macmillan.

Danet, B., \& Herring, S. (2007). The Multilingual Internet: Language, Culture, and Communication Online. Oxford University Press.

Hirt, S., Ferenčuhová, S., \& Tuvikene, T. (2016). Conceptual forum: The "post-socialist" city. Eurasian Geography and Economics, 57(4-5), 497-520.

Irvine, T., \& Gal, S. (2012). Language Ideology and Linguistic Differentiation. In P. V. Kroskrity (Ed.), Regimes of Language: Ideologies, Polities and Identities (pp. 35-84). School of America Research Press.

Lücke, M., \& Saha, D. (2019) Labour migration from Ukraine: Changing destinations, growing macroeconomic impact. German Advisory Group, Policy Studies Series.

Sevük, T. (2013). The influence of Facebook on interpersonal communication. Eastern Mediterranean University (EMU)-Doğu Akdeniz Üniversitesi (DAÜ).

Facebook. Ukrainians in Germany. Retrieved from_https://www.facebook.com/groups/624314044433235

Facebook. Ukrainians in Berlin. Retrieved from https://www.facebook.com/groups/2161546170739893

Association of Ukrainian Organizations in Germany. Retrieved from https://www.dach-ukraine.de/uk

German-Ukrainian Association Rhine-Neckar. Retrieved from http://www.dug-rhein-neckar.de/uk

\begin{abstract}
Анастасія Кузнєцова. Використання мови та формування ідентичності українських онлайн співтовариств у Німеччині. Ця стаття вивчає використання мови та іїі відношення до ідентичності українських громад у Німеччині на веб-сайтах та в соціальних мережах. Починаючи з 2014 року, конфлікт на Сході України призвів до надзвичайно великого та інтенсивного потоку українських мігрантів до Західної Європи та Німеччини, зокрема, породжуючи давні проблеми формування ідентичності та використання мови як в Україні, так і всередині українських діаспорних спільнот світу. У цій статті розглянуті мовні ідеології, практики та формування ідентичності української діаспори в Німеччині шляхом аналізу ii мовної онлайн-активності. Для цього наш аналіз спирається на низку міждисциплінарних методологій, включаючи попередні описові звіти онлайндискусій діаспор, їх мовні практики та ставлення до мови, а також дослідження дискурсивного формування національної ідентичності. Зазначено, що українська мова використовується як мова за замовчуванням на веб-сайтах та у спілкуванні в соціальних мережах і $є$ центральною у цих взаємодіях (німецька та російська мови використовуються в значно меншій мірі).
\end{abstract}

Ключові слова: ідентичність; використання мови; основна мова; соціальні медіа; українська діаспора. 